\title{
CONSTRUCTIONAL PROFILE OF THE VERBAL PREFIX ZA-: A COMPARATIVE STUDY OF RUSSIAN AND POLISH
}

\author{
SVETLANA SOKOLOVA \& WOJCIECH LEWANDOWSKI \\ University of Tromsø, Universitat Autònoma de Barcelona
}

ABSTRACT

In this paper we investigate the semantic and syntactic properties of the prefix zA- in Russian and Polish against the background of the Locative Alternation. We provide lists of alternating verbs for Russian and Polish and examine their occurrences with the prefix zA- as presented in the Russian National Corpus and the Polish National Corpus. While the literature on the prefix ZA- mainly offers semantic analysis, we look at the "constructional profile" of $\mathrm{zA}^{-}$, i.e. the relative frequency distribution of the two locative constructions for each ZA-verb. Our data suggest that there are both similarities and differences in the syntactic behavior of the corresponding ZAverbs in Russian and Polish, although in general there is a strong tendency for ZA- to be used in the Goal-Object construction. We provide evidence that both constructions are possible with verbs like 'hang' and 'pour', which, according to lexical approaches, should not alternate. Our study fortifies the idea that prefixes and constructions correlate and that the Locative Alternation is construction-driven. The data analyzed also indirectly supports the classification of alternating verbs as "manner", "path" and "hybrid".

\section{[1] INTRODUCTION}

In this paper we present empirical data related to several theoretical issues. The first issue involves the semantics of the prefix zA- in two related languages, Russian and Polish, which are often considered to be similar in their use of verbal prefixes. We investigate the semantics of the prefix zA- against the background of the second issue, namely the "Locative Alternation", a current issue in research on argument structure.The Locative Alternation phenomenon manifests itself in the use of a verb in two different structures, such as John loaded the hay onto the truck (Theme-Object construction) vs. John loaded the truck with hay (Goal-Object construction). The question of what motivates such variation still puzzles linguists. Given the list of alternating verbs developed for other European languages, we provide lists of corresponding verbs for Russian and Polish and examine their occurrences with the prefix zA-. While the literature on the prefix zA- mainly of- 
fers semantic analysis, we focus on both semantic and syntactic properties of zAby looking at its "constructional profile" (Janda \& Solovyev 2009), i.e. the relative frequency distribution of the two locative constructions for each zA-verb. The data are extracted from the Russian National Corpus (www.ruscorpora.ru, henceforth RNC) and the Polish National Corpus (www.nkjp.pl, PNC) respectively. Our data suggest that there are both similarities and differences in the constructional behavior of the corresponding verbs with zA- in Russian and Polish, although in general there is a strong tendency for ZA- to be used in the Goal-object construction. We provide evidence that both constructions are possible with verbs like 'hang' and 'pour', which, according to lexical approaches, should not alternate. This way our study fortifies the idea that prefixes and constructions correlate and that the Locative Alternation is "construction-driven" (Goldberg 1995, 2006). Moreover, the data analyzed also support Lewandowski's (2009) classification of alternating verbs as "manner", "path" and "hybrid".

We start with a brief overview [2] of the main theoretical issues, namely the semantics of the prefix zA- in Russian and Polish [2.1] and the Locative Alternation [2.2], placing specific focus on the classification of alternating verbs [2.3]. Our objectives are to test the similarities and differences in the distribution of alternating zA-verbs in Polish and Russian, and in this way deduce information about the semantics of $\mathrm{zA}$ - in both languages. We present an empirical study of our data extracted from the corpora [3.1] using the method of constructional profiling [3.2]. The analysis [4] addresses the relationship between the semantics of the verb, the prefix and the Locative Alternation. Conclusions are offered in [5].

\section{[2] THEORETICAL ISSUES}

Russian and Polish are considered to be similar in the way their verbal prefixes function, especially when opposed to languages that do not have derivational means for expressing aspectual relations. The similarities between the two languages are also emphasized by Dickey's 2000; 2005 classification of aspectual patterns. This section provides the reader with a general outline of the scholarly literature on the semantics of the prefix zA- in Slavic languages and the Locative Alternation.

\section{[2.1] The semantics of the prefix za-}

The semantic properties of the prefix zA- in Russian and Polish are much debated among Slavic linguists. Researchers are concerned with how the prefix is used as both a resultative prefix, referring to an accomplished action, and as an inceptive prefix, marking the beginning of an action or a state (Golovin 1964; Ovčinnikova 1979; Sokolova 1982; Wróbel 1984; Janda 1985; Śmiech 1986; Dickey 2000; Tabakowska 2003; Zaliznjak 2006), etc.). Another property of ZA- is its productivity and frequency in word formation (Pavlova 1988; Čertkova 1996; Łaziński 2008). 
The majority of works dealing with the semantics of zA- in Russian follow either a lexicographical tradition (Golovin 1964; Švedova et al. 1980) or a structuralist approach (Ovčinnikova 1979; Sokolova 1982). Lexicographers describe the derivational types of verbs with the prefix $\mathrm{ZA}^{-}$, some of which are related to each other (Golovin 1964), while structuralists view the semantics of ZA- as a smaller set of unrelated senses, or distinctive features (Ovčinnikova 1979; Sokolova 1982). Similarly to the situation in Russian, the Polish prefix zA- has traditionally been analyzed as a list of different senses, which can be characterized as either contributing to the verb some kind of Aktionsart information or deriving verbs with a new lexical meaning (Wróbel 1984; Śmiech 1986). The main senses of zA- in Russian and Polish most frequently distinguished in the literature on verbal prefixation are summarized in Table 1 on the following page.

As can be seen from the overview, the basic meanings of Russian and Polish ZA- appear to be very similar. Additionally, with some predicates zA- has been considered a pure marker of perfectivity, where the only difference between the unprefixed verb and its prefixed counterpart with zA- (or Natural Perfective, as in Janda's terminology) is that of imperfective vs. perfective. For Russian, this applies to the resultative use of zA- as in (6) and some examples of "covering" (3b) and "filling" (4b) (Ožegov \& Švedova 2001). In Polish, this is the case of verbs like zaśpiewać 'sing-PFV' (14) where, according to (Kurzowa 1997, 17) zA- is devoid of semantic content.

The structuralist approach was significantly revised in a more recent work by Zaliznjak (2006), where the prefix ZA- is characterized by a certain set of semantic features (or a "conceptual schema"), such as primary BEHIND, IN, EDGE, UP, DEVIA, FAR, and derived COVER, HIDE (from BEHIND) and BECOME, BEGIN, FIX (from IN), which in different combinations appear in verbs with zA- (Zaliznjak 2006, 311). The semantic type of the ZA-verb is calculated on the basis of semantic features of the prefix, the properties of the unprefixed base verb, and the argument structure of the unprefixed verb. Importantly, Zaliznjak emphasizes the role of the argument structure in defining the semantic type of the zA-verb, although she does not discuss whether zA- affects the constructions in which the verb is used. In section [4], we illustrate that not only can ZA- change the basic constructional properties of the unprefixed verb, but it can also provide conditions for alternation.

An alternative approach is presented by Janda $(1985,1986)$ for Russian and by Tabakowska (2003) for Polish, who describe different meanings of zA- in terms of a cognitive radial network. Janda points out that although a prefix appears to be semantically fractured, certain submeanings are related to each other and can be presented as a set of configurations (or spatial image-schemas). A configuration consists of a landmark and a trajector which moves in relation to it. Thus, the central configuration for $\mathrm{zA}$ - can be described as the trajector transgressing the 
TABLE 1: The main meanings of the prefix zA- in Russian and Polish.

\begin{tabular}{|c|c|c|c|}
\hline \multicolumn{2}{|c|}{ Meanings } & Russian & Polish \\
\hline \multirow{6}{*}{ 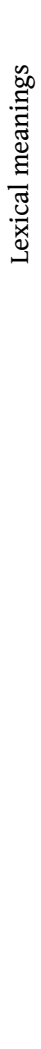 } & $\begin{array}{l}\text { moving behind } \\
\text { something }\end{array}$ & $\begin{array}{l}\text { (1) zabežat' (za ugol) } \\
\text { za-run (behind corner-ACC) } \\
\text { 'run around the corner' }\end{array}$ & $\begin{array}{l}\text { (9) zajechać (za róg) } \\
\text { za-drive (behind corner- ACC) } \\
\text { 'drive around the corner' }\end{array}$ \\
\hline & deflection & $\begin{array}{l}\text { (2) zajti (k drugu) } \\
\text { za-walk (to friend-DAT) } \\
\text { 'drop by a friend's house' }\end{array}$ & $\begin{array}{l}\text { (10) zajść (do kolegi) } \\
\text { za-walk (to friend-GEN) } \\
\text { 'drop by a friend's house' }\end{array}$ \\
\hline & covering & $\begin{array}{l}\text { (3) a. zastroit' } \\
\text { za-build } \\
\text { 'build up an area with new } \\
\text { blocks or flats' } \\
\text { b. zakrasit' } \\
\text { za-paint } \\
\text { 'cover with paint' }\end{array}$ & \begin{tabular}{|l} 
(11) a. zalesić \\
za-forest \\
'plant with trees' \\
b. zamalować \\
za-paint \\
'cover with paint'
\end{tabular} \\
\hline & filling & $\begin{array}{l}\text { (4) a. zapolnit' } \\
\text { za-fill } \\
\text { 'fill' } \\
\text { b. zaplombirovat' } \\
\text { za-fill a tooth } \\
\text { 'fill a tooth' }\end{array}$ & \begin{tabular}{|l} 
(12) a. zapetnić \\
za-fill \\
'fill' \\
b. zaplombować \\
za-fill a tooth \\
'fill a tooth'
\end{tabular} \\
\hline & $\begin{array}{l}\text { getting } \\
\text { possession } \\
\text { of something }\end{array}$ & $\begin{array}{l}\text { (5) zaxvatit' } \\
\text { za-seize } \\
\text { 'seize, take over, capture' }\end{array}$ & $\begin{array}{l}\text { (13) zawojować } \\
\text { za-wage war } \\
\text { 'conquer' }\end{array}$ \\
\hline & $\begin{array}{l}\text { reaching natural } \\
\text { endpoint }\end{array}$ & $\begin{array}{l}\text { (6) zaregistrirovat' } \\
\text { za-register } \\
\text { 'register' }\end{array}$ & $\begin{array}{l}\text { (14) zaśpiewać } \\
\text { za-sing } \\
\text { 'sing' }\end{array}$ \\
\hline \multirow{3}{*}{ 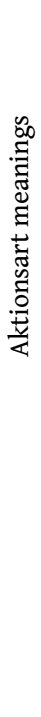 } & inceptive & $\begin{array}{l}\text { (7) a. zapet' } \\
\text { za-sing } \\
\text { 'begin singing' } \\
\text { b. zacvesti } \\
\text { za-blossom } \\
\text { 'begin blossoming' }\end{array}$ & $\begin{array}{l}\text { (15) a. zapłonać } \\
\text { za-burn } \\
\text { 'begin burning' } \\
\text { b. zakwitnaćc } \\
\text { za-blossom } \\
\text { 'begin blossoming' }\end{array}$ \\
\hline & intensive & $\begin{array}{l}\text { (8) a. zaxvalit' } \\
\text { za-praise } \\
\text { 'overpraise, to lionize' } \\
\text { b. zagovorit'sja } \\
\text { za-talk Refl } \\
\text { 'get excessively absorbed in } \\
\text { talking' }\end{array}$ & $\begin{array}{l}\text { (16) a. zaspać } \\
\text { za-sleep } \\
\text { 'oversleep, sleep too long' } \\
\text { b. zagadać się } \\
\text { za-talk Refl } \\
\text { 'get excessively absorbed in } \\
\text { talking' }\end{array}$ \\
\hline & terminative & & $\begin{array}{l}\text { (17) a. zajechać (do wsi) } \\
\text { za-go into village } \\
\text { 'go into (the village)' } \\
\text { b. b. zaszybować (do miasta) } \\
\text { za-glide into town } \\
\text { 'glide into (the town)' }\end{array}$ \\
\hline
\end{tabular}


boundary of the landmark and passing into the area outside the landmark (Janda 1985, 29).

In terms of such interaction between the trajector and the landmark it is possible to account for various seemingly unrelated senses of zA-. Tabakowska shows that the inceptive sense of $\mathrm{ZA}^{-}$, illustrated in (15), is a metaphorical extension of the central spatial sense, in which the landmark is conceptualized as an abstract boundary separating "non-action" from "action" (Tabakowska 2003, 168). The apparently paradoxical terminative sense is based, as Tabakowska demonstrates, on the same notion of "passable borderline" with the difference that this borderline is part of the landmark, expressed as part of the prepositional phrase. On the other hand, the covering meaning relies, according to Tabakowska's analysis, on the so-called sense of curtain (cf. Weinsberg (1973)): the trajector covers the landmark, so that the latter is hidden behind the former and cannot be seen, accessed, etc. If the action of covering extends to the entire landmark, zA- implies "filling", as in (12).

Quite importantly, both in the traditional approaches (cf. (Golovin 1964; Ovčinnikova 1979; Śmiech 1986)), as well as (although to a lesser extent) in more recent accounts (Tabakowska 2003; Zaliznjak 2006), it is argued that different senses of a given prefix are verb-class specific, i.e. they are compatible with different semantic classes of verbs. Here, it will be shown that the different senses of zA- are not only verb class-specific, but also construction-specific. In particular, it will be shown that each variant of the locative alternation is associated with a different meaning of zA-. The next two sections provide the relevant information on the Locative Alternation and its relation to verbal roots.

\section{[2.2] Different approaches to alternating verbs}

The Locative Alternation is a phenomenon attested in many languages, where a given verb can occur in two alternative constructions (see (18), (19)), both of which deliver approximately the same information:

(18) John loaded the hay onto the truck. (Theme-Object construction)

(19) John loaded the truck with hay. (Goal-Object construction)

The terminology which is used to denote the two constructions is diverse. In this work, we follow Brinkmann (1997); Nichols (2008) and Sokolova et al. (forthcoming) in naming the constructions Theme-Object and Goal-Object as above. The hay item stands for the theme and the truck item for the goal, while "object" refers to the direct object, which in Russian and Polish is consistently coded with the Accusative case in both constructions.

The works on the Locative Alternation can be divided into three major groups, according to the approach they use: (1) sYNTACTIC/LEXICAL (Rappaport Hovav \& 
Levin 1988, 2005, 2008; Pinker 1989; Levin 1993; Brinkmann 1997; Dowty 2000) (2) FRAME (Fillmore 1968, 1977, 2008; Boas 2001, 2006) (3) CONSTRUCTIONAL (Goldberg 1995, 2006; Michaelis \& Ruppenhofer 2001; Iwata 2005, 2008). Each approach in its own way addresses the question of what motivates the Locative Alternation. The syntactic/lexical approach focuses on the meaning of the verb, treating the syntactic options as secondary to the intrinsic properties of the verb ("contentoriented" or "container-oriented") (Pinker 1989, 125-127). Within existing classifications of verbal roots, it is problematic to account for all the occurrences of the Locative Alternation, since some verbs which are classified as 'non-alternating' can alternate under certain circumstances (see Boas (2006) for some counterexamples). The frame approach takes the syntactic construction as the point of departure, showing how different constructions are related to each other within bigger frames. Words like load are split into separate lexical units, depending on the semantic frames they evoke. Yet, the focus on the frame makes it less evident why a single verb alternates between constructions (for more detail, see Sokolova et al. (forthcoming).

According to the constructional approach, the Locative Alternation is an epiphenomenon of the compatibility between the verbal meaning and two independently existing constructions (Goldberg 2006, 40). Our data support Goldberg $(1995,2002,2006)$ and Michaelis \& Ruppenhofer (2001) in that the Locative Alternation is construction-driven with a reference to verbal semantics. In the next section we will discuss different ways to classify verbal roots with regard to the Locative Alternation.

\section{[2.3] Different approaches to verbal roots}

Manner vs. Result

It has been widely assumed that verbs from various lexical fields can be classified as lexicalizing manner (e.g. wipe, float) or result/path (e.g. clean, enter). Levin \& Hovav (1991) postulate that manner and result/path are in complementary distribution: a verb can codify either one or the other meaning component, but not both at the same time. Even if some verbs refer to results brought about using a conventionally associated manner or, analogically, some manner verbs specify actions performed to bring about a conventionally associated result, only one of these semantic components is codified in the verbal root. The other can only be expressed outside the verb. For instance, although the action of "wiping" is usually used to clean a surface, the verb wipe only denotes a manner of motion (which can be characterized as "surface contact"), whereas the final state of the surface is codified in a separate linguistic unit, i.e. the adjectival phrase clean (20):

(20) Pat wiped the table clean. 
On the other hand, Talmy $(1985,2000)$ shows that the manner/path dichotomy is relevant for characterizing crosslinguistic lexicalization patterns. He argues that languages can be categorized as either VERB-FRAMED, such as Romance or Turkish, or SATELLITE-FRAMED, such as Germanic and Slavic. Whereas the former lexicalize the path of motion in the verb and express the manner, if specified, in a secondary element (e.g. a prepositional phrase or a Gerund), the latter codify the manner of motion in the verb, with the Path being relegated to a secondary element, commonly a preposition or prefix, cf. (21) and (22).

(21) La botella entró en la cueva (flotando). [Spanish] the bottle entered in the cave floating 'The bottle entered the cave (floating).'

(22) The bottle floated into the cave.

Manner and path distinction as a gradient phenomenon

Although it is an uncontroversial fact that there are prototypical manner or path/result verbs, as Levin \& Hovav (1991); Rappaport Hovav \& Levin (1998) and Talmy $(1985,2000)$ convincingly demonstrate, it has been postulated that a strict dichotomy is empirically not justifiable. Lewandowski (2009) classifies verbs entering into the locative alternation in Polish and Spanish as "manner", "path" and "hybrid". Manner verbs, such as Polish chlapać, Spanish salpicar 'splatter' provide information about how the action denoted by the verb is performed (in this particular case, the liquid is distributed in a wide-spread fashion; cf. Pinker (1989). Path verbs, such as Polish wieszać, Spanish colgar 'hang', clearly imply displacement of the theme. In contrast, hybrid verbs lexicalize both manner of motion and path. For instance, Polish ładować, Spanish cargar 'load' implies that a large quantity of items is displaced, but since items are usually loaded into a container, this verb also evokes the trajectory "outside-inside". Lewandowski (2009, forthcoming) shows that the distribution of the alternating verbs in one or the other pattern of the locative alternation is statistically different depending on the root type. Overall, manner verbs tend to appear more often in the Goal-Object construction, and path verbs in the Theme-Object construction, while the distribution of hybrid verbs is similar in both constructions.

In this paper, we follow Lewandowski's classification of alternating verbs and provide evidence that the hybrid nature of verbal roots is also relevant for the grammatical profile of prefixes.

\section{[3] DATA AND METHODOLOGY}

Our study examines the constructional profiles of the alternating zA-verbs in Russian and Polish as evidenced by data from the RNC and the PNC. We first describe how our data were extracted and coded and then present our methodology. 


\section{[3.1] Data. Alternating za-verbs in Russian and Polish}

The list of alternating verbs for Russian and Polish

Following the classification of Lewandowski (2009), we compose a list of alternating verbs for Russian and Polish, which comprise three major groups: "manner", "path" and "hybrid". The lists of such verbs are given below:

Two groups of MANNER VERBS: ${ }^{1}$.

a) Wide-spread or undirected distribution of a liquid

$\begin{array}{ll}\text { Russian: } & \text { Polish: } \\ \text { bryzgat' 'splatter' } & \text { bryzgać 'splatter' } \\ \text { pryskat' 'spray' } & \text { pryskać 'spray' }\end{array}$

b) Contact of a mass against a surface

$\begin{array}{ll}\text { Russian: } & \text { Polish: } \\ \text { mazat' 'daub, smear' } & \text { mazać 'daub' } \\ & \text { smarować 'smear' }\end{array}$

"Manner" verbs do not codify path: you can smear something up, down, to the left, to the right, etc. Thus, path is underspecified in their verbal meaning and they are more likely to be used in the Goal-object construction.

PATH VERBS:

$\begin{array}{ll}\text { Russian: } & \text { Polish: } \\ \text { klast' 'lay'2 } & \text { kłaść 'lay' } \\ \text { vešat' 'hang' } & \text { wieszać 'hang' } \\ \text { stavit' 'stand' } & \text { stawiać 'stand' }\end{array}$

"Path" verbs imply path, i.e. they denote movement of the theme from one place to another. The prediction will be that they favor the Theme-Object construction.

HYBRID VERBS:

Russian: Polish:

gruzit' 'load' ładować 'load'

pakovat' 'pack' pakować 'pack'

pixat' 'stuff pchać 'stuff'

lit' 'pour' lać 'pour'

sypat' 'strew' sypać 'strew'

[1] The characterization of the manner component is taken from Pinker (1989), who claims that alternation does not extend to verbs of "pure manner of motion" such as pour, verbs of force exertion (push, drag, pull, tug, yank) or verbs of positioning (lay, place, position, put) since there is no way to predict on the basis of the verb meaning alone what the effect on the goal argument will be (Pinker 1989, 80). 
"Hybrid" verbs are associated with a particular manner of displacing things, but at the same time all of them evoke a container, involving the directionality "outside-inside", cf. Section [2.2]. These verbs can put the focus on both participants and this way have the potential to occur in both constructions.

When used with prefixes, the verbs listed above can behave in three different ways:

(a) Some verbs can alternate when unprefixed. For Russian, this is the case with bryzgat' 'splatter', mazat' 'smear, daub', gruzit' 'load', pakovat' 'pack', whereas for Polish it is the case of all the verbs, except pchać 'stuff' and the positional verbs kłaść 'lay', wieszać 'hang' and stawiać 'stand'.

(b) Other verbs do not alternate without a prefix and can be used either in the Theme-Object or Goal-Object construction depending on the prefix. For instance, the Russian unprefixed verb stavit 'put, place', as well as its Natural Perfective with PO- (postavit'), are used in Theme-Object construction, while its perfectives with ZA- and ов- choose the Goal-object construction (zastavit' 'cover something with standing objects'; obstavit 'furnish'). In Polish, we find a similar effect with the verbs pchać 'stuff', kłaść 'lay', wieszać 'hang' and stawiać 'stand', which appear in the Theme-Object construction without a prefix but favor the Goal-object construction when used with a resultative prefix like zA- or OB- (zapchać 'stuff, choke', obłożyć 'cover by putting things on a surface', zawiesić 'cover by hanging things on a surface', zastawic 'cover by standing things on a surface, block access').

(c) Finally, some Russian verbs do not alternate when unprefixed but can be used in both constructions with certain prefixes. This is the case of Russian zalit' 'pour', zasypat' 'strew', zavešat'/zavesit' 'hang', založit 'lay' with the prefix zA-.

\section{Examples considered in this study}

To the Russian and Polish verbs from the list above, we add the prefix zA- and investigate how such prefixed versions of the base verbs are represented in the corpora. For the purpose of this study, we used the Modern subcorpus (20002009) of the $\mathrm{RNC}^{3}$, which contains 53 million words, and the PNC, containing 350 million words. For both Russian and Polish, we extracted all occurrences of each ZA-verb from the corpora, excluding passive participles ${ }^{4}$, and manually coded the examples as Theme-Object vs. Goal-Object.

[3] We used the modern subcorpus of the RNC since it is most equivalent with the PNC, which includes only modern texts.

[4] The contexts with passive participles require a separate investigation since they present examples of the Locative Alternation where the focus on one of the participants is greater than in the contexts with non-passive forms. However, the general assumption is that the distribution of passive forms between the two constructions resembles the situation with non-passive forms, as far as the choice of the main construction, see Sokolova et al. (forthcoming). 
The Theme-Object and Goal-Object constructions differ in which of the participants is marked as the direct object: the Theme (i.e. elements like hay), or the Goal (i.e. elements like truck). In both constructions in Russian and Polish the direct object is consistently coded with the Accusative case, while the second participant can be expressed via different forms. The Theme-Object construction encodes the Goal via a prepositional phrase with a noun in the Accusative case, as illustrated in (23) and (24). In the Goal-Object construction the second participant is coded by the Instrumental case without a preposition in (25) and (26):

THE THEME-OBJECT CONSTRUCTION

(23) Voditel' zagruzil paket v bagažnik [Russian]

Driver-NOM loaded bag-ACC in trunk-ACC

'The driver loaded the bag into the trunk'

(24) Smuga natychmiast polecił załadować zapasy jarzyn na

Smuga at once ordered za-load provisions vegetables-GEN on

łodzie [Polish]

boats-ACC

'Smuga ordered that the vegetables be loaded onto the boats immediately'

THE GOAL-OBJECT CONSTRUCTION

Tam krasnoarmejcy zagruzili kuzov jaščikami $[\mathrm{Ru}]$ There Red-Army-soldiers-NOM za-loaded truck-bed-ACC boxes-INS 'There the Red Army soldiers loaded the truck bed with boxes'

(26) Chciałem załadować armatę pociskiem (...) i dobić go. [Polish] I wanted za-load tank-ACC projectile-INS (...) and finish him 'I wanted to load the tank with a projectile and kill him'

The Theme-Object construction focuses on the Theme and on the change of its location. For instance, (23) concentrates on what happens to the bag, i.e. the Theme. On the other hand, the Goal-object construction marks the change of the state of the Goal, as in (25), which is about the truck bed and how it is loaded.

The two constructions of the Locative Alternation can be represented via full constructions where both participants (Theme and Goal) are overtly expressed, as well as via "reduced constructions", where one of the participants is missing. Most cases with the omitted Theme or Goal argument are instances of ellipsis since the missing participant is perceived from the context. Example (27) below illustrates a Theme-Object construction with a missing Goal: 
(27) Tol'ko zagruzit' ugol' budet problematično, poskol'ku iz-za Just load coal-ACC will-be problematic, since due-to moroza on prevratilsja $\mathrm{v}$ glyby. [Russian] frost-GEN it-NOM turned-into into blocks-ACC.

'Just getting the coal loaded will be problematic since due to the cold it has turned into blocks.'

In our research we aggregate data from both the full constructions and the reduced constructions. The only examples extracted from our analysis are constructions which can be characterized as hybrid. This means that one of the components of the classical locative construction is expressed by a different form, as in (28) below:

(28) Italija, ešče vcera otkazavšajasja ukryt' u sebja Italy-NOM only yesterday refuse-ACT NOM to hide by self-GEN prestupnikov ... segodnja rešila "zamazat" v nravstvennom criminals-ACC ... today decided to daub in moral prestuplenii drugie strany Evropy. [Russian] crime-LOC other countries-ACC Europe-GEN 'Italy, which only yesterday refused to give shelter to the criminals, today has decided to accuse other European countries of moral crime'

In (28), the first participant is marked by Accusative case, while the second element is in the Locative case. Thus, it is not obvious whether the first element stands for the Theme or the Goal.

\section{[3.2] Methodology}

The method used in this study is "constructional profiling", i.e. "the frequency distribution of the constructions that a word appears in", based on corpus data (Janda \& Solovyev 2009, 367). This methodology is inspired by construction grammar, as it treats the construction as the relevant unit of linguistic analysis (Goldberg 1995, 2006) and implies that speakers are sensitive to the frequency of words in constructions (Goldberg 2006, 46, 62). On the one hand, the constructional profile is a more focused version of the behavioral profile, which involves a wide range of factors (collocational, morphosyntactic, syntactic, and semantic) to investigate synonymy (Divjak 2006; Divjak \& Gries 2006). On the other hand, constructional profiling takes the word as the point of departure and in this sense is the inverse of the collostructional methodology, which starts with a construction and investigates what words can occur in it (Stefanowitsch \& Gries 2003, 2005).

The constructional profiles of the alternating zA-verbs in Russian and Polish presented in this study show in which sense the two languages can be treated as similar and in which way they differ. 


\section{[4] ANALYSIS}

First, we aim to investigate the similarities and the differences in the distribution of the alternating ZA-verbs in Russian and Polish. Second, by comparing the constructional profiles of the zA-verbs, we analyze the semantics of ZA- in the two languages and the relation between the semantics of the verb, the prefix and the locative alternation.

The data frequencies, collected as described in section [3], are presented in Tables 2 and 3 on the facing page.

\begin{tabular}{|l|l|l|l|l|l|l|}
\hline \multirow{2}{*}{ Verb } & Gloss & \multicolumn{2}{c|}{$\begin{array}{c}\text { Theme-Object } \\
\text { construction }\end{array}$} & \multicolumn{2}{c|}{$\begin{array}{c}\text { Goal-Object } \\
\text { construction }\end{array}$} & \multicolumn{1}{|c|}{ Total } \\
\hline & & $\begin{array}{c}\text { raw } \\
\text { frequency }\end{array}$ & $\begin{array}{c}\text { relative } \\
\text { frequency }\end{array}$ & $\begin{array}{c}\text { raw } \\
\text { frequency }\end{array}$ & $\begin{array}{c}\text { relative } \\
\text { frequency }\end{array}$ & \\
\hline zapryskat' & 'spray' & 0 & $0 \%$ & 0 & $0 \%$ & 0 \\
\hline zabryzgat' & 'splatter' & 0 & $0 \%$ & 28 & $100 \%$ & 28 \\
\hline zamazat' & $\begin{array}{c}\text { 'daub, } \\
\text { smear' }\end{array}$ & 0 & $0 \%$ & 56 & $100 \%$ & 56 \\
\hline zagruzit' & 'load' & 85 & $47.8 \%$ & 93 & $52.2 \%$ & 178 \\
\hline zapakovat' & 'pack' & 13 & $100 \%$ & 0 & $0 \%$ & 13 \\
\hline zapixat' & 'stuff' & 63 & $100 \%$ & 0 & $0 \%$ & 63 \\
\hline zasypat' & 'strew' & 36 & $17 \%$ & 176 & $83 \%$ & 212 \\
\hline zalit' & 'pour' & 59 & $11.8 \%$ & 440 & $88.2 \%$ & 499 \\
\hline $\begin{array}{l}\text { zavešat'/ } \\
\text { zavesit' }\end{array}$ & 'hang' & 2 & $8.7 \%$ & 21 & $91.3 \%$ & 23 \\
\hline zastavit' & 'stand' & 0 & $0 \%$ & 5 & $100 \%$ & 5 \\
\hline založit' & 'lay' & 238 & $96.7 \%$ & 8 & $3.3 \%$ & 246 \\
\hline
\end{tabular}

TABLE 2: Locative Alternation among non-passive forms of Russian alternating verbs.

Given the relative frequencies in Tables 2 and 3 on the facing page, we end up with the following constructional profiles of the alternating zA-verbs for Russian and Polish (see Figures 1 and 2 on page 378).

As can be seen from Figures 1 and 2, the verbs that favor the Goal-object construction in both Russian and Polish are: 'splatter' (Russian zabryzgat'), 'smear' and 'daub' (Russian zamazat' and Polish zasmarować, zamazać), 'strew' (Russian zasypat', Polish zasypać), 'pour' (Russian zalit', Polish zalać) and 'stand' (Russian zastavit', Polish zastawić ). On the other hand, the verbs for 'pack' (Russian zapakovat', Polish zapakować) and 'lay' (Russian založit', Polish założyć) show a preference

[5] Since only one example of zabryzgać 'splatter' was attested in the corpus we will treat it as 0 . 


\begin{tabular}{|l|l|l|l|l|l|l|}
\hline \multirow{2}{*}{ Verb } & Gloss & \multicolumn{2}{c|}{$\begin{array}{c}\text { Theme-Object } \\
\text { construction }\end{array}$} & \multicolumn{2}{c|}{$\begin{array}{c}\text { Goal-Object } \\
\text { construction }\end{array}$} & Total \\
\hline & & $\begin{array}{c}\text { raw } \\
\text { frequency }\end{array}$ & $\begin{array}{c}\text { relative } \\
\text { frequency }\end{array}$ & $\begin{array}{c}\text { raw } \\
\text { frequency }\end{array}$ & $\begin{array}{c}\text { relative } \\
\text { frequency }\end{array}$ & \\
\hline zapryskać & 'spray' & 0 & $0 \%$ & 0 & $0 \%$ & 0 \\
\hline zabryzgać & 'splatter' & 0 & $0 \%$ & 1 & $(100 \%)^{5}$ & 1 \\
\hline zasmarować & 'smear' & 0 & $0 \%$ & 21 & $100 \%$ & 21 \\
\hline zamazać & 'daub' & 0 & $0 \%$ & 33 & $100 \%$ & 33 \\
\hline załadować & 'load' & 471 & $81.8 \%$ & 105 & $18.2 \%$ & 576 \\
\hline zapakować & 'pack' & 507 & $94.9 \%$ & 27 & $5.1 \%$ & 534 \\
\hline zapchać & 'stuff' & 0 & $0 \%$ & 69 & $100 \%$ & 69 \\
\hline zasypać & 'strew' & 1 & $0.2 \%$ & 572 & $99.8 \%$ & 573 \\
\hline zalać & 'pour' & 2 & $0.5 \%$ & 383 & $99.5 \%$ & 385 \\
\hline zawiesić & 'hang' & 578 & $99.3 \%$ & 4 & $0.7 \%$ & 582 \\
\hline zastawić & 'stand' & 0 & $0 \%$ & 241 & $100 \%$ & 241 \\
\hline założyć & 'lay' & 789 & $100 \%$ & 0 & $0 \%$ & 789 \\
\hline
\end{tabular}

TABLE 3: Locative Alternation among non-passive forms of Polish alternating verbs.

for the Theme-Object construction. The differences between the two languages concern the verbs for 'load' (a preference towards the Theme-Object construction in Polish and an even distribution between the two constructions in Russian), the verbs for 'stuff' (Theme-Object construction in Russian and the Goal-Object construction in Polish), and the verbs for 'hang' (the Russian verb favors the GoalObject construction, while the Polish one is only attested in the Theme-Object construction). It can also be seen that Russian and Polish are characterized by a different number of verbs that show a variation between the two constructions.

The similarities and differences between the alternating zA-verbs in Russian and Polish are discussed in the subsections below.

\section{[4.1] General tendencies in the alternating za-verbs in Russian and Polish}

The analysis of the alternating verbs in Russian and Polish shows that the semantics of the prefix is construction-specific. When the Goal-object construction is "headed" by zA-, the prefix bears the meaning of "covering" (cf. Russian zabryzgat', zamazat', zastavit'; Polish zasmarować, zamazać, zasypać, zalać, zastawić) or "filling" (as in Russian zagruzit'; Polish zapchać). On the other hand, when zA- appears in the Theme-object construction, it has the meaning of reaching a natural endpoint (Russian zagruzit', zapakovat'; Polish załadować, zapakować) or "placing" (Russian zapixat', založit'; Polish założyć). 


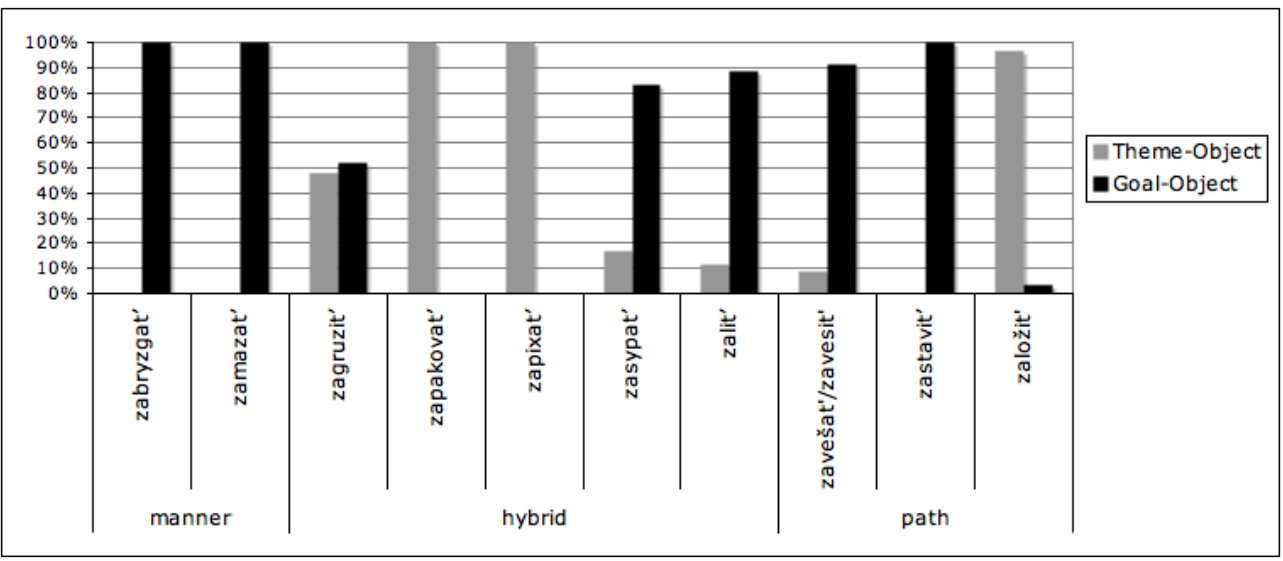

FIGURE 1: Constructional profile of the prefix ZA- in Russian.

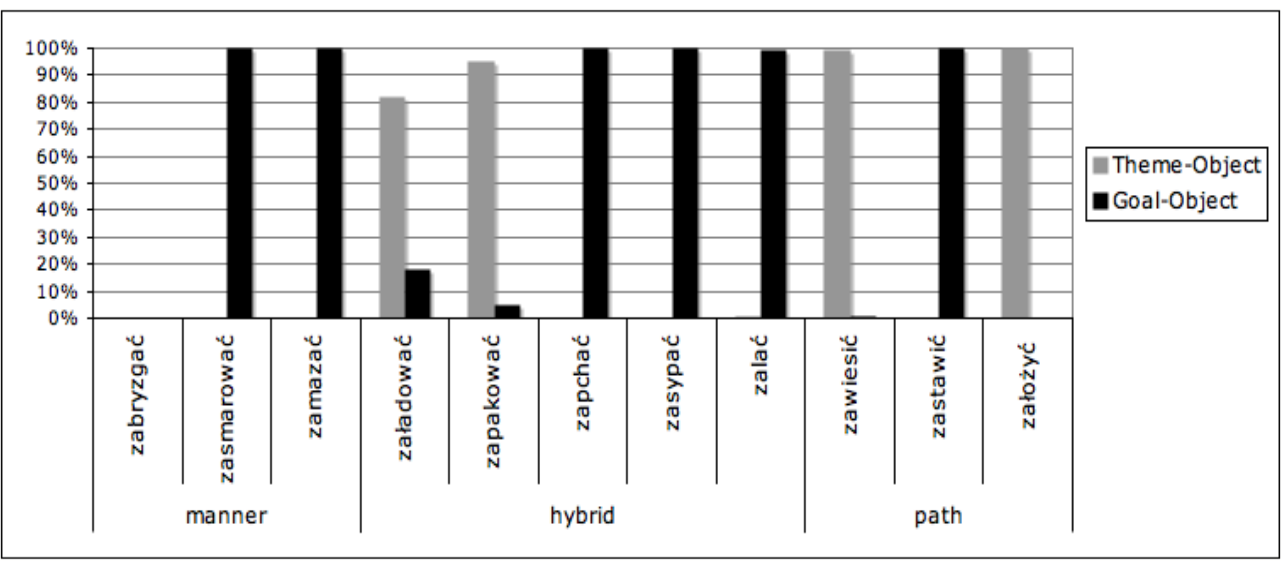

FIGURE 2: Constructional profile of the prefix zA- in Polish.

As can be seen from Figures 1 and 2 above, in both Russian and Polish, "manner" verbs are clearly associated with the "change of state" meaning. This could be due to the general tendency for verbs with a strong manner component to avoid constructions describing displacement than "hybrid" or "path" verbs. In other words, the manner component "clashes" to a certain degree with the displacement or "change of location" meaning. For instance, in Polish, "manner" verbs, unlike "hybrid" verbs, systematically reject spatial prefixes like w- 'in', Do'into' (Lewandowski forthcoming):

(29) “Hybrid” verbs: wpakować 'in-pack', włożyć 'in-lay', wlać 'in-pour', wsypać 'in-strew'; dopakować 'into-pack', dołożyc 'into-lay', dolać 'into-pour', dosypać 'into-strew' 
“Manner" verbs: *wpryskać 'in-spray', *wbryzgać 'in-splatter', *wmazać 'in-daub'; 'dopryskać 'into-spray', *dobryzgać 'into-splatter', *domazać 'intodaub'.

On the other hand, "path" and "hybrid" verbs differ from "manner" verbs in that most of them appear in both constructions (Russian zagruzit', zasypat', zalit', zavešat'/zavesit', založit'; Polish załadować, zapakować and very sporadically zawiesić, zasypać, zalać, where the attested frequency for one of the constructions is below $1 \%)$ ). The proportion between the Theme-Object and the Goal-Object constructions for "hybrid" verbs depends on the idiosyncratic properties of individual verbs, first of all on the degree to which the Theme is specified. For instance, zalit' 'pour' indicates the Theme as a liquid, so the focus is usually placed on the Goal, which is modified. The verb zasypat' 'strew' presents the Theme as a dry substance (small objects that are perceived as a mass) with a somewhat higher frequency of the Theme-Object construction than in the case of zalit'. The Theme of the verb gruzit' 'load' is a single heavy object or a number of separate objects (which are not presented as a mass), which gives more opportunities for profiling either the Theme or the Goal. Thus, the closer the Theme of the verb is to a count noun, the more even the distribution between the constructions appears to be, since the focus can be placed on both participants. However, this hypothesis requires testing on a larger amount of data.

Another common effect for both Russian and Polish is that zA- seems to be more frequent in the Goal-Object construction, which indicates that there is a certain correlation between the construction and the prefix. In Russian, uprefixed "manner" verbs usually occur in the Goal-Object construction, while "hybrid" and "path" verbs favor the Theme-Object construction. In addition, the "manner" verbs bryzgat' 'splatter', mazat' 'smear, daub' and the "hybrid" verbs gruzit' 'load', pakovat' 'pack' can alternate between the two constructions, still showing a stronger preference towards either the Goal-Object construction (in the case of "manner" verbs) or the Theme-Object construction (in the case of "hybrid" verbs). The choice for the Theme-Object or Goal-Object construction within Polish unprefixed "manner" and "hybrid" verbs is similar to Russian, with the only difference that in Polish all unprefixed "manner" and "hybrid" verbs, except for pchać 'stuff', potentially alternate (the verb pchać 'stuff' and the positional verbs are categorically excluded from the Goal-object frame when unprefixed). The correlation of the prefix zA- with the Goal-Object construction reveals itself in two ways: first, zA- eliminates alternation within the "manner" verbs, strengthening the status of the Goal-Object construction, second, it shifts many "hybrid" and "path" verbs from the Theme-Object construction to the Goal-Object construc- 
tion (cf. the verbs zagruzit', zasypat', zalit', zavešat'/zavesit', zastavit' in Figure 1 on page 378 and zapchać, zasypać, zalać and zastawić in Figure 2 on page 378).

The use of each zA-verb is generally skewed in favor of one of the locative constructions. The only exception is the Russian verb zagruzit' 'load', where the distribution between the Theme-Object and the Goal-Object constructions is almost even (Theme-Object: 47.8\%; Goal-Object: 52.2\%). A more elaborate analysis of the examples indicates that this could be due to the number of additional metaphorical uses that this verb has in the Goal-Object construction. As shown in Sokolova (2010), of the three prefixed counterparts to the verb gruzit' 'load' (with prefixes ZA-, NA- and PO-), zagruzit' is more often used metaphorically: zagruzit' is characterized by $39 \%$ of metaphorical uses, while nagruzit' and pogruzit' have $25 \%$ and $11 \%$ respectivly. The major metaphorical extensions of zagruzit' involve a "person" (Goal), who serves as the metaphorical CONTAINER, and "information" or "work" (Theme), which represent metaphorical CONTENTs, as shown in (30)(31):

Ah, vam interesny podrobnosti iz žizni Oh, you-DAT are-interesting particulars-NOM from life-GEN zvezd? Radi boga, Andrej Maksimov "zagruzit" pop-stars-GEN? For god, Andrej Maksimov-NOM za-load-FUT vas ètoj informaciej. [Russian] you-ACC this-INS information-INS 'Oh, you are interested in the details of the life of our pop stars? No problem, Andrej Maksimov will provide you with this information.'

Zasedanie Gossoveta po kul'ture zagruzit rabotoj Meeting-NOM State-Council-GEN on culture-DAT za-load-FUT work-INS sotrudnikov Minsterstva kul'tury na bližajšie neskol'ko members-ACC Ministry-GEN Culture-GEN for nearest-ACC few-ACC let. [Russian] years-GEN 'The agenda of the State Council on Culture will keep the members of the Ministry of culture busy for several years.'

It is remarkable that in non-metaphorical uses, zagruzit' favors the Theme-Object construction (68.7\%), resembling the situation in Polish (see Table 4 on the facing page). However, in metaphorical contexts, it is skewed towards the Goal-Object construction (70.5\%).

As can bee seen from Figure 3 on page 382, zagruzit' 'load' is the only Russian alternating verb where metaphorical contexts have a crucial affect on the general distribution between the Theme-Object and the Goal-Object constructions because the two contexts behave so differently. It is also the verb that has the 


\begin{tabular}{|c|c|c|c|c|c|l|}
\hline \multirow{2}{*}{ Verb } & Extension & \multicolumn{2}{|c|}{$\begin{array}{c}\text { Theme-Object } \\
\text { construction }\end{array}$} & \multicolumn{2}{|c|}{$\begin{array}{c}\text { Goal-Object } \\
\text { construction }\end{array}$} & Total \\
\hline & & $\begin{array}{c}\text { raw } \\
\text { frequency }\end{array}$ & $\begin{array}{c}\text { relative } \\
\text { frequency }\end{array}$ & $\begin{array}{c}\text { raw } \\
\text { frequency }\end{array}$ & $\begin{array}{c}\text { relative } \\
\text { frequency }\end{array}$ & \\
\hline $\begin{array}{c}\text { zagruzit' } \\
\text { 'load' }\end{array}$ & non-metaphorical & 57 & $68.7 \%$ & 26 & $31.3 \%$ & 83 \\
\cline { 2 - 7 } & metaphorical & 28 & $29.5 \%$ & 67 & $70.5 \%$ & 95 \\
\hline $\begin{array}{c}\text { zasypat' } \\
\text { 'strew' }\end{array}$ & non-metaphorical & 35 & $20.5 \%$ & 136 & $79.5 \%$ & 171 \\
\cline { 2 - 7 } & metaphorical & 1 & $2.4 \%$ & 40 & $97.6 \%$ & 41 \\
\hline $\begin{array}{c}\text { zalit' } \\
\text { 'pour' }\end{array}$ & non-metaphorical & 50 & $11.6 \%$ & 381 & $88.4 \%$ & 431 \\
\cline { 2 - 7 } $\begin{array}{c}\text { zavešat'/ } \\
\text { zavesit' } \\
\text { 'hang' }\end{array}$ & mon-metaphorical & 9 & $13.2 \%$ & 59 & $86.8 \%$ & 68 \\
\cline { 2 - 7 } & metaphorical & 0 & $0 \%$ & 2 & $100 \%$ & 2 \\
\hline založit' & non-metaphorical & 115 & $94 \%$ & 7 & $6 \%$ & 122 \\
\cline { 2 - 7 } 'lay' & metaphorical & 123 & $99.2 \%$ & 1 & $0.8 \%$ & 124 \\
\hline
\end{tabular}

TABLE 4: The distribution of the two locative constructions among metaphorical and non-metaphorical contexts within Russian alternating verbs that are attested in both constructions.

highest percentage of metaphorical contexts: for zagruzit', metaphorical extensions constitute $53.4 \%$ of all the contexts; for založit' this number amounts to $50 \%$; zasypat' has $19.3 \%$ of metaphorical uses, while zalit' and zavesit' show only $13.6 \%$ and $8.7 \%$. The percentage of the metaphorical contexts for the verb založit' is also high since most of its Theme-Object usages are represented by frequently used collocations like založit' fundament/ osnovu 'lay the foundation' (36.6\% of all uses). Cf. example (32):
Vmeste oni
zalozili osnovu
novogo
stilja
Together they-NOM laid foundation-ACC new-MASC.GEN style-GEN
nacional'noj muzyki. [Russian]
national-FEM.GEN music-GEN
'Together, they established a new style for national music.'

Thus, the overall tendency is that alternating verbs prefer one construction over the other, given that there are no other factors interfering, like metaphor.

\section{[4.2] Differences between the alternating za-verbs in Russian and Polish}

As shown in the previous subsection, the Russian and Polish alternating verbs have a lot in common. Yet, our analysis also points to some differences between the two languages. Firstly, in Russian, more verbs with the prefix zA- are attested 


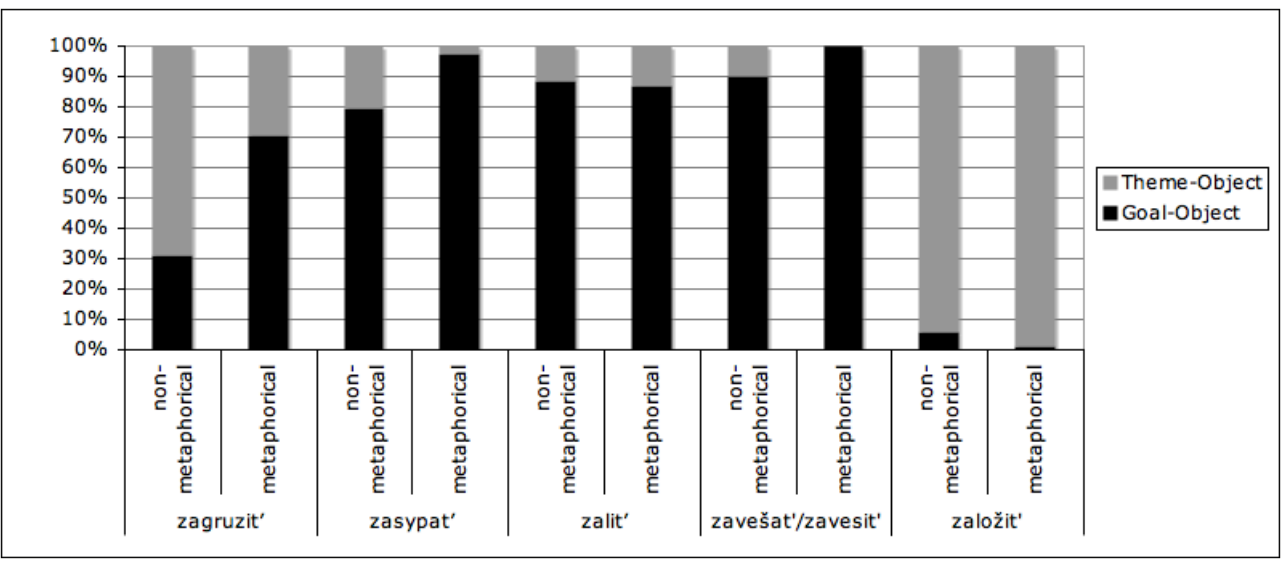

FIGURE 3: The distribution of the two locative constructions among metaphorical and non-metaphorical contexts within Russian alternating verbs that are attested in both constructions.

in both constructions. Leaving aside the Russian verb zavešat'/zavesit' 'hang' for which we have little data, we are still left with three verbs (zagruzit' 'load', zasypat' 'strew', zalit' 'pour'), where the frequency of the secondary construction is above $10 \%$. For Polish this is the case only for załadować 'load'. The Polish zA- therefore shows a stronger preference for one of the constructions, depending on the semantics of the verbal root, while in Russian there is a whole group of $\mathrm{zA}$-verbs that can alternate. The arrangement of the group of verbs that show constructional variation can be summarized as follows: the Russian and Polish verbs for 'load' show the highest variation between the two constructions; other potentially alternating verbs are 'strew', 'pour' and 'hang', where a relatively high variation is attested only for Russian. Finally, the Polish data indicate variation for 'pack' whereas the Russian data has variation for 'lay'.

The Goal-Object construction takes only $5 \%$ of the total uses of 'pack' in Polish, as in examples like (33):
Zapakujemy plecak piwem i będziemy się integrować $\mathrm{z}$ we-pack-FUT satchel-ACC beer-INS and we-will REFL integrate with gośćmi.
guests-INS
'We will pack the bag with beer and then we will mingle with the guests.'

In the case of Russian 'pack', we have too little data to claim that this verb can't alternate at all, although our examples can be perceived as indirect evidence that the dominant construction here is the Theme-Object construction, resembling 
the situation in Polish. Internet pages contain examples like (34), which indicate that the behavior of the verbs for 'pack' in Russian and Polish is quite similar:

$$
\begin{aligned}
& \text { Est' dva čemodana: odin ja xoču } \\
& \text { Be two-NOM suitcases-GEN: one-ACC I-NOM want-PRES.1SG } \\
& \text { zapakovat' ličnymi veščami, drugoj podarkami } \\
& \text { za-pack-INF personal-INS things-INS, another-ACC presents-INS } \\
& \text { 'I have two suitcases: one of then I want to pack with my personal things } \\
& \text { and the other one with presents' } \\
& \text { (chemodan.eu/news/2008/01/4373.html?Page=5) }
\end{aligned}
$$

The Russian example (34) profiles the Goal (suitcases) as the direct object and the Theme (personal things) as the noun phrase in the Instrumental case and is thus parallel to the Polish example (33), where the bag (Goal in the Accusative case) is packed with beer (Theme in the Instrumental case).

It is remarkable that the corresponding zA-verbs in Russian and Polish usually prefer the same construction. However, our data record two opposing cases: the verbs for 'hang', where the Russian zavesit' favors the Goal-Object construction and the Polish zawiesić chooses the Theme-Object construction, and the verbs for 'stuff', with the Russian zapixat' attested only in the Theme-Object construction and the Polish zapchać attested only in the Goal-Object construction.

A mismatch between Russian and Polish in the case of 'hang' can be accounted for by tracing the differences in the prototype of $\mathrm{zA}$ - in the two languages. It appears that the Russian zA- is strongly associated with a container. In particular, this idea is supported by the distribution of zA- with spatial prefixes NA 'on' and $\mathrm{v}$ 'in'. For instance, the unprefixed verb gruzit' 'load' does not set any restrictions on the type of the Goal (i.e. information whether the Goal is a container or a surface) and shows an even distribution between the container-oriented preposition $\mathrm{v}$ and the surface-oriented preposition NA that introduce the Goal in the Accusative case. However, its Natural Perfective with zA- strongly prefers the container-oriented V ( $88 \%$ vs. $12 \%$ with NA), while NA-perfective favors the surface-oriented preposition NA, see (Sokolova et al. forthcoming). It is plausible that when added to the Russian alternating verbs, zA- as a rule shifts the focus from the Theme to the Goal. Yet, a ZA-verb can be used with the Theme-Object construction if the Goal is a container. For instance, in (35)-(36), the Russian verb zasypat' 'strew' has the same Theme (the gravel). When the Goal is a surface, as in (35), only the Goal-Object construction is used.

(35) Kogda vse rastenija budut vysaženy, zasyp'te ploščadku When all-NOM pants-NOM be-FUT planted, za-strew-IMP ground-ACC graviem gravel-INS 
'Once the plants are planted out, strew the ground with gravel.'

Cf.

$\left(35^{\prime}\right)$ ??Zasyp'te gravij na ploščadku

za-strew-IMP gravel-ACC on ground-ACC

'Strew the gravel on the ground.'

At the same time, the Theme-Object construction is possible with the same Theme (the gravel) if the Goal represents a container, which is usually headed by the preposition $\mathrm{v}$ :

$$
\begin{aligned}
& \text { Zasyp'te gravij V akvarium } \\
& \text { za-strew-IMP gravel-ACC into aquarium-ACC } \\
& \text { 'Strew the gravel into the aquarium.' } \\
& \text { (minibiohome.com/manual_aquasaurs.php) }
\end{aligned}
$$

Even when the Goal of the verb zasypat' is marked by the preposition NA, it still refers to a container:

$$
\begin{aligned}
& \text { Na dno tranšei zasyp'te gravij } \\
& \text { On bottom-ACC ditch-GEN za-strew-IMP gravel-ACC } \\
& \text { 'Strew the bottom of the ditch with gravel.' } \\
& \text { (www.mukhin.ru/home/decoland/30.html) }
\end{aligned}
$$

However, if the Goal of a verb is almost never a container, a shift in the construction occurs, as in the case of zamazat' 'smear', which is attested only in the GoalObject construction. The verb zamazat' gains an additional meaning of "covering" and "hiding" the Goal, making it inaccessible (38):

$$
\begin{aligned}
& \text {... a kraskoj zamaž'te nadpisi na stenax } \\
& \ldots \text { and paint-INS za-smear-IMP inscriptions-ACC on walls-LOC } \\
& \text { pod"ezdov } \\
& \text { entrances-GEN } \\
& \text { '...and use the paint to cover up the messages on the walls in the en- } \\
& \text { trances.' }
\end{aligned}
$$

We might assume that the Russian ZA-, which is associated with "crossing a boundary", presupposes that the trajector is always INSIDE or BEHIND the landmark. As a result, Russian sets a restriction on the use of zavesit' 'hang' in the Theme-Object construction since the Goal of 'hang' is always a surface. It seems that Polish doesn't have such restrictions, thus allowing for the use of zawiesic 'hang' in the Theme-Object construction. 
The second reverse case, attested in the verbs for 'stuff', occurs due to a significant shift in meaning of the Polish verb zapchać. Unprefixed pchać usually means 'push', referring to the situations of 'pushing on a door', 'pushing a baby carriage' or 'pushing a person', which use the "change of location" pattern. When prefixed with zA-, it gains the meaning 'stuff' or 'choke', placing the focus on the Goal and changing the construction:

Rozpostarłem gazete i (...) zapchałem usta
I spread-PAST newspaper-ACC and (...) I stuffed mouth-ACC
obeschniętym plackiem.
dry-INS biscuit-INS

'I opened the newspaper and (...) I stuffed my mouth with a dry biscuit.'

On the other hand, the Russian verbs pixat' and zapixat', despite certain functional differences, both share the meaning 'stuff', as can be seen in (40)-(41), and can be used in the same, Theme-Object, construction:
Ded
uspeval
prosledit', skol'ko
šokoladnyx
Grandfather managed-IPFV trace-INF, how-many chocolate-GEN
konfet ... zapixali
sebe $\mathrm{v}$ rot
deti.
sweets-GEN ... za-stuff-PAST.3PL refl-DAT in mouth-ACC children-NOM
'Grandfather was able to keep track of how many chocolates the children stuffed into their mouths.'

$$
\begin{aligned}
& \text {... ne vse pixajut sebe } \mathrm{v} \text { rot po dva } \\
& \text {... not all-NOM stuff refl-DAT in mouth-ACC by two-ACC } \\
& \text { buterbroda srazu } \\
& \text { sandwiches-GEN at-once } \\
& \text { 'Not everybody stuffs his mouth with two sandwiches at once' } \\
& \text { (http://forum.privet.com/viewtopic.php?f=4\&t=27310\&start=125) }
\end{aligned}
$$

In addition to a comparative analysis of the way the alternating zA-verbs function in Russian and Polish, our data also make a crucial contribution to the general discussion on the Locative Alternation with regard to verbal roots. The properties demonstrated by the Russian zA-verbs like zavešat' 'hang', as well as the selection of the Goal-Object construction by the Russian verbs zalit' 'pour', zastavit' 'put in a standing position' and the corresponding Polish verbs zalać, zastawić, present counterexamples to Pinker's claim that verbs like 'hang', 'pour' and 'put' should not appear in the change of state pattern. Thus, the occurrence of the Locative Alternation with such verbs cannot be described in terms of verbal semantics only but should be rather treated as a complex interaction of the verbal root, the construction and the prefix, which is closely related to the construction. 


\section{[5] CONCLUSIONS}

The ZA- verbs in Russian and Polish show both similarities and differences in their syntactic behavior. On the one hand, the semantics of the prefix zA- in both languages is construction-specific: when used with the Goal-object construction, the prefix refers to "covering" or "filling", whereas in the Theme-object construction, it bears the meaning of "reaching a natural endpoint" or "placing". In both Russian and Polish, the ZA-verbs prefer the Goal-Object construction, supporting the idea that prefixes correlate with constructions. In particular, in both Russian and Polish, zA- eliminates alternation within the "manner" verbs, making the GoalObject construction more prominent, and shifts many "hybrid" and "path" verbs from the Theme-Object construction to the Goal-Object construction. The use of each zA-verb is generally skewed in favor of one of the locative constructions. The one exception is the Russian verb zagruzit' 'load', where an almost even distribution between the Theme-Object and the Goal-Object constructions appears to be the result of additional metaphorical uses in the Goal-Object construction.

On the other hand, some Russian and Polish alternating ZA-verbs behave differently. Firstly, more Russian zA-verbs alternate between the two constructions: cf. Russian zagruzit', zasypat', zalit', zavešat'/zavesit', založit' vs. Polish załadować, zapakować. Another difference is that although the corresponding zA-verbs in Russian and Polish usually prefer the same construction, two opposing cases exist: the verbs for 'hang' (where Russian zavesit' favors the Goal-object construction and the Polish zawiesic the Theme-Object construction), and the verbs for 'stuff' (the Russian zapixat' is attested only in the Theme-Object construction and the Polish zapchać in the Goal-Object construction). A mismatch between Russian and Polish in the case of 'hang' is motivated by the fact that the Russian ZA- is strongly associated with a container. As a result, Russian sets a restriction on the use of zavesit' 'hang' in the Theme-Object construction since the Goal of 'hang' is always a surface. The second case can be accounted for via a significant shift in meaning, which occurs in the Polish verb pchać 'push'. When prefixed with zA-, it gains the meaning 'stuff' or 'choke', placing the focus on the Goal and changing the construction.

Our analysis also contributes to the study of the Locative Alternation. First, our findings indirectly support the division of the alternating verbs into "manner", "path" and "hybrid". In both Russian and Polish, "manner" verbs are clearly associated with the "change of state" meaning and are not attested in the ThemeObject construction. On the other hand, "path" and "hybrid" verbs differ from "manner" verbs in that some of them appear in both locative constructions. The proportion of the Theme-Object and Goal-Object constructions for "hybrid" verbs depends on the idiosyncratic properties of individual verbs, first of all on the degree to which the Theme is specified: the closer the Theme of the verb is to a 
count noun, the more even the distribution between the constructions appears to be.

Moreover, our case study suggests that the prefix zA- is the prefix that allows verbs typically associated with the change of location pattern to appear in the change of state construction (cf. the Russian verb zavešat' 'hang'). This goes against Pinker (1989), who claims that verbs like 'hang' or 'pour' should not appear in the change of state pattern. As our data from Russian and Polish show, such a shift is possible when the corresponding verbs are prefixed with zA-.

Further elaboration of this topic requires a thorough comparison of the data described in this article with the corresponding unprefixed alternating verbs. Some other issues for future investigation are metaphorical extensions of the Theme-Object and the Goal-Object constructions in both languages and hybrid constructions.

\section{ACKNOWLEDGMENTS}

The major part of this research was made possible due to a grant from the Norwegian Research Council in support of the "Exploring Emptiness", a research group at the University of Tromsø. It has aslo been supported by the grants HUM200613295-C02-02 of the Spanish Ministery of Science and Innovation, and SGR-007532005 of the Generalitat de Catalunya.

\section{REFERENCES}

Boas, H. C. 2001. A lexical-constructional account of the locative alternation. In L. Carmichael, C.-H. Huang \& V. Samiian (eds.), Proceedings of the 2001 Western Conference in Linguistics 13, 27-42.

Boas, H. C. 2006. A frame-semantic approach to identifying syntactically relevant elements of meaning. In P. Steiner, H. C. Boas \& S. Schierholz (eds.), Contrastive Studies and Valency. Studies in Honor of Hans Ulrich Boas, 119-149. Frankfurt.

Brinkmann, U. 1997. The locative alternation in German. Its structure and acquisition. Amsterdam: John Benjamins.

Dickey, S. M. 2000. Parameters of Slavic aspect: A cognitive approach. Stanford: CSLI.

Dickey, S. M. 2005. S-/z- and the grammaticalization of aspect in Slavic. Slovene Linguistic Studies (5).

Divjak, D. 2006. Ways of intending: Delineating and structuring near-synonyms. In S. Gries \& A. Stefanowitsch (eds.), Corpora in Cognitive Linguistics: The Syntaxlexis Interface, vol. 2, 19-56. Berlin: Mouton de Gruyter. 
Divjak, D. \& S. T. Gries. 2006. Ways of trying in Russian: clustering behavioral profiles. Corpus Linguistics and Linguistic Theory 2. 23-60.

Dowty, D. 2000. The fallacy of 'argument alternation'. In Y. Ravin \& C. Laecock (eds.), Polysemy, 111-128. Oxford: Oxford University Press.

Fillmore, C. F. 2008. Border Conflicts: FrameNet Meets Construction Grammar. [Presented as a plenary talk at Euralex 2008].

Fillmore, C. J. 1968. The Case for Case. In E. Bach \& R. T. Harms (eds.), Universals in linguistic theory, 1-88. New York.

Fillmore, C. J. 1977. The Case for Case Reopened. In P. Cole (ed.), Syntax and Semantics. Grammatical Relations, vol. 8, 59-81. New York Academic Press.

Goldberg, A. E. 1995. Constructions. A Construction Grammar Approach to Argument Structure. Chicago: The University of Chicago Press.

Goldberg, A. E. 2002. Surface Generalizations: an alternative to alternations. Cognitive Linguistics 13(4). 327-356.

Goldberg, A. E. 2006. Constructions at Work: The Nature of Generalizations in Language. Oxford: Oxford U Press.

Golovin, B. N. 1964. Slovoobrazovatel'nyje tipy glagolov s pristavkoj ZA-. Voprosy teorii i vuzovskogo prepodavanija russkogo jazyka. Učenyje zapiski Gor'kovskogo gosudarstvennogo universiteta 68. 47-70.

Iwata, S. 2005. Locative alternation and the two levels of verb meaning. Cognitive Linguistics 16(2). 355-407.

Iwata, S. 2008. Locative Alternation: A lexical-constructional approach. Amsterdam: John Benjamins.

Janda, L. A. 1985. The meaning of Russian verbal prefixes: Semantics and grammar. In The scope of Slavic aspect, 26-40.

Janda, L. A. 1986. A Semantic Analysis of the Russian Verbal Prefixes ZA-, PERE-, DOand OT. Munich: Otto Sagner.

Janda, L. A. \& V. Solovyev. 2009. What Constructional Profiles Reveal About Synonymy and Metaphor: A Case Study of Russian words for 'sadness'. Cognitive Linguistics 20(2). 367-393.

Kurzowa, Z. 1997. Tackling Polish verbs. Kraków: Baran \& Suszczyński. 
Łaziński, M. 2008. The prefix ZA- in contemporary Polish against the Slavic background. In Abstracts of the Third International Conference Perspectives on Slavistics, 28-31. Hamburg.

Levin, B. 1993. English verb classes and alternations: a preliminary investigation. Chicago: University of Chicago Press.

Levin, B. \& M. Rappaport Hovav. 1991. Wiping the Slate Clean. Cognition 41. 123-151.

Lewandowski, W. 2009. A corpus-based analysis of the locative alternation in Polish and Spanish. In Presentation at the Fourth Annual Meeting of the Slavic Linguistic Society, University of Zadar, Croatia.

Lewandowski, W. forthcoming. La alternancia locativa en castellano y polaco: un análisis tipológico-construccional. Universitat Autònoma de Barcelona.

Michaelis, L. \& J. Ruppenhofer. 2001. Valence Creation and the German Applicative: the Inherent Semantics of Linking Patterns. Journal of Semantics 17(4). 335-395.

Nichols, J. 2008. Prefixation and the Locative Alternation in Russian contact verbs. In Presentation at the annual conference of the American Association of Teachers of Slavic and East European Languages, San Francisco.

Ovčinnikova, A. V. 1979. Tipologija značenij glagol'noj pristavki ZA-. In Materialy po russko-slavjanskomu jazykoznaniju, vol. 7, 110-116. Voronež: Izdatel'stvo Voronežskogo universiteta.

Ožegov, S. I. \& N. Ju Švedova. 2001. Slovar' russkogo jazyka. Moscow: Russkij jazyk.

Pavlova, N. I. 1988. Semantičeskij potencial prefiksov v russkom slovoobrazvanii (na materiale izučenija slovoobrazovatel'nogo polja s prefiksom ZA-). In Edinstvo sistemnogo i funkcional'nogo analiza jazykovyx edinic, Belgrad.

Pinker, S. 1989. Learnability and cognition: The acquisition of argument structure. Cambridge, Mass.: MIT Press.

Rappaport Hovav, M. \& B. Levin. 1988. What to do with theta-roles. In W. Wilkins (ed.), Syntax and semantics: Thematic relations, vol. 21, 7-36. San Diego: Academic Press.

Rappaport Hovav, M. \& B. Levin. 1998. Building Verb Meanings. In M. Butt \& W. Geuder (eds.), The Projection of Arguments, 97-134. Stanford: CSLI Publications. 
Rappaport Hovav, M. \& B. Levin. 2005. Change of State Verbs: Implications for Theories of Argument Projection. In N. Erteschik-Shir \& T. Rapoport (eds.), The Syntax of Aspect, 274-286. Oxford: Oxford University Press.

Rappaport Hovav, M. \& B. Levin. 2008. Reflections on Manner/Result Complementarity.

Śmiech, W. 1986. Derywacja prefiskalna czasowników polskich. Wrocław: Ossolineum.

Sokolova, S., O. Lyashevskaya \& L. Janda. forthcoming. The Locative Alternation and the Russian 'empty' prefixes: A case study of the verb GRUZIT' 'load'. In Frequency effects in cognitive linguistics: what statistical effects can(not) explain, vol. 2 Trends in Linguistics Series, Berlin: Mouton de Gruyter.

Sokolova, S. O. 1982. O differencial'nykh semantičeskikh priznakakh glagol'noj pristavki ZA- v russkom jazyke. Problemy leksičeskoj i kategorial'noj semantiki 2. $32-41$.

Stefanowitsch, A. \& S. T. Gries. 2003. Collostructions: Investigating the interaction of words and constructions. International Journal of Corpus Linguistics 8. 209-243.

Stefanowitsch, A. \& S. T. Gries. 2005. Covarying collexemes. Corpus Linguistics and Linguistic Theory 1. 1-43.

Tabakowska, E. 2003. Space and time in Polish: the preposition ZA and the verbal prefix ZA-. In H. Cuyckens et al. (eds.), Motivation in Language. Studies in honor of Günter Radden, 153-177. Amsterdam: John Benjamins.

Talmy, L. 1985. Lexicalization patterns: Semantic structure in lexical forms. In T. Shopen (ed.), Language typology and syntactic description: Grammatical categories and the lexicon, vol. 3, 57-149. Cambridge, UK: Cambridge University Press.

Talmy, L. 2000. Towards a cognitive semantics II: Typology and process in concept structuring. Cambridge, MA: MIT Press.

Čertkova, M. J. 1996. Grammatičeskaja kategorija vida v sovremennom russkom jazyke. Moscow: Moscow State University.

Švedova, N. Ju et al. 1980. Russkaja grammatika, vol. I. Moscow: Nauka.

Weinsberg, A. 1973. Przyimki przestrzenne w języku polskim, niemieckim i rumuńskim. Wrocław: Ossolineum.

Wróbel, H. 1984. Słowotwórstwo czasowników. In R. Grzegorczykowa et al. (eds.), Gramatyka współczesnego języka polskiego, 467-512. PWN, Warszawa. 
Zaliznjak, A. A. 2006. Mnogoznačnost' v jazyke i sposoby ee predstavlenija. Moscow: Jazyki slavjanskikh kul'tur.

AUTHOR CONTACT INFORMATION

Svetlana Sokolova

Department of Language and Linguistics

University of Tromsø

Norway

Svetlana.Sokolova@uit.no

Wojciech Lewandowski

Centre de Lingüística Teòrica

Universitat Autònoma de Barcelona

Spain

Wojciech.Lewandowski@uab.cat 